\title{
"Measuring the competition and banking efficiency level: a study at four commercial banks in Indonesia"
}

\begin{tabular}{|c|c|}
\hline \multirow{3}{*}{ AUTHORS } & Setyo Tri Wahyudi iD https://orcid.org/0000-0003-4779-5747 \\
\hline & Rihana Sofie Nabella iD https://orcid.org/0000-0003-3943-9240 \\
\hline & Kartika Sari id https://orcid.org/0000-0002-5688-2394 \\
\hline ARTICLE INFO & $\begin{array}{l}\text { Setyo Tri Wahyudi, Rihana Sofie Nabella and Kartika Sari (2021). Measuring the } \\
\text { competition and banking efficiency level: a study at four commercial banks in } \\
\text { Indonesia. Banks and Bank Systems, 16(1), 17-26. } \\
\text { doi:10.21511/bbs.16(1).2021.02 }\end{array}$ \\
\hline DOI & http://dx.doi.org/10.21511/bbs.16(1).2021.02 \\
\hline RELEASED ON & Wednesday, 13 January 2021 \\
\hline RECEIVED ON & Tuesday, 14 July 2020 \\
\hline ACCEPTED ON & Tuesday, 08 December 2020 \\
\hline & $((c)) \overline{E Y}$ \\
\hline LICENSE & $\begin{array}{l}\text { This work is licensed under a Creative Commons Attribution } 4.0 \text { International } \\
\text { License }\end{array}$ \\
\hline JOURNAL & "Banks and Bank Systems" \\
\hline ISSN PRINT & $1816-7403$ \\
\hline ISSN ONLINE & $1991-7074$ \\
\hline PUBLISHER & LLC “Consulting Publishing Company "Business Perspectives" \\
\hline FOUNDER & LLC "Consulting Publishing Company "Business Perspectives" \\
\hline & 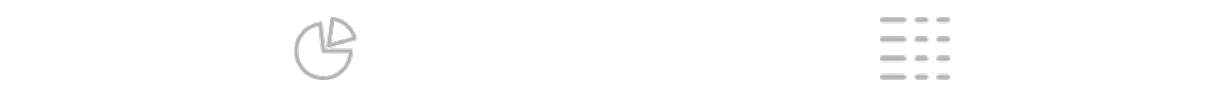 \\
\hline NUMBER OF REFERENCES & NUMBER OF FIGURES \\
\hline 31 & 3 \\
\hline
\end{tabular}

(c) The author(s) 2021. This publication is an open access article. 


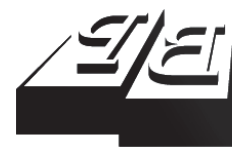

\section{BUSINESS PERSPECTIVES}

LLC "CPC "Business Perspectives" Hryhorii Skovoroda lane, 10, Sumy, 40022, Ukraine www.businessperspectives.org
Received on: $14^{\text {th }}$ of July, 2020 Accepted on: $8^{\text {th }}$ of December, 2020 Published on: $13^{\text {th }}$ of January, 2021

(C) Setyo Tri Wahyudi, Rihana Sofie Nabella, Kartika Sari, 2021

Setyo Tri Wahyudi, Ph.D., Associate Professor, Senior Lecturer, Faculty of Economics and Business, Brawijaya University, Indonesia. (Corresponding author)

Rihana Sofie Nabella, Master of Economics, Faculty of Economics and Business, Brawijaya University, Indonesia.

Kartika Sari, Master of Economics, Faculty of Economics and Business, Brawijaya University, Indonesia.
Setyo Tri Wahyudi (Indonesia), Rihana Sofie Nabella (Indonesia),

Kartika Sari (Indonesia)

\section{MEASURING}

THE COMPETITION AND

BANKING EFFICIENCY LEVEL:

\section{A STUDY AT FOUR COMMERCIAL BANKS IN INDONESIA}

\begin{abstract}
The banking sector plays a vital role in the economy of each country. Banks are required to operate in a sound, efficient, and reliable manner in order to stimulate economic growth. To achieve that, a basic framework for the Indonesian banking system has been developed, known as the Indonesian Banking Architecture (IBA) aimed at strengthening the structure and enhancing the competitiveness of the banking industry. This study aimed to analyze the level of competition, the ability, and influence of the competition on banks efficiency, so banks can maintain the performance level and provide economic growth. This study used a quantitative approach with a panel regression analysis model. The results have shown that the banking industry in Indonesia tends to be monopolistic. The character of many sellers, differentiated products, sellers freely entering and leaving the market, as well as the presence of advertisement and product quality competitions were examined. Bank competition that leads to a monopolistic market structure stimulated banks to achieve higher profits and put bank projects and financing at high risk. Competition had a negative correlation with bank efficiency because competition encourages banks to focus on profit rather than efficiency, engage in risky financing/projects, and undertake high lending activities. Moreover, four big banks in Indonesia are in the "too big to fail" position. Banking regulators in Indonesia must maintain and produce reliable and stable banks to compete globally.
\end{abstract}

\section{Keywords banking, efficiency, finance, industry, market structure}

\section{JEL Classification E47, G28, L10}

\section{INTRODUCTION}

The banking sector plays an important role in the country's economy. It has a significant impact on supporting economic activity. For Indonesia, the banking sector is still the primary source of capital for the community. Banks play a role in stimulating the domestic economy. Suseno and Abdullah (2003) mentioned three functions of banks at a macro level: the central role, payment traffic services, and monetary policy transmission media. The Financial Services Authority (2018a) shows a positive growth trend in the commercial banks' crediting over the past three years. That is, the role of banks in stimulating the domestic economy is increasing.

Understanding the significant role of banks in the domestic economy is vital to maintaining the soundness of banks. Disrupting a bank's soundness would ultimately hamper the bank's function as an intermediary institution (Utama, 2006). Currently, banks are required to operate in a sustainable, efficient, and robust manner in order to stimulate economic growth. The three core banking functions then become the vision for the Indonesian banking industry (Financial Services Authority, 2004). 
To achieve a healthy, efficient, and robust banking system, a basic framework for the Indonesian banking system has been developed, known as the Indonesian Banking Architecture (IBA). The IBA is aimed at strengthening the structure and enhancing the competitiveness of the banking industry. These two objectives can be achieved with several programs; one program is the consolidation of banks to strengthen capital positions (Financial Services Authority, 2004).

This consolidation program, in turn, had an impact on changes in the market structure of the banking industry. Theoretically, the consolidation or merger caused a decrease in the level of competition in one sector (Financial Services Authority, 2004). In the next few years, the market structure of the banking industry has the potential to become an oligopoly market and may even form an extreme monopoly.

The creation of market structures, both oligopoly and monopoly, in turn, affects bank performance, especially the ability to improve efficiency. Monopoly power is negatively related to a company's incentives to improve efficiency (Nguyen \& Nghiem, 2017). The higher the power of monopoly, the more the industry tends to be inefficient. However, some previous studies have shown different results. For example, previous research from Williams (2012) proved that monopoly power through privatization policies was a factor driving the efficiency of domestic banks. This happened because the privatization policy stimulated competition in the banking industry in Latin America.

Much research had been done on competition and banking efficiency. Naceur et al. (2009) examined the efficiency of competition in the Middle Eastern and North African countries (MENA). The study showed that market concentration and proxy from the competition reduce bank efficiency. Meanwhile, Abbasoglu et al. (2007) showed that with the presence of large banks, the market tended to be concentrated, and these large banks tended to be more efficient. In their research, Schaeck and Čihák (2008) tested two hypotheses, namely the Competition Efficiency Hypothesis and the Competition-Inefficiency Hypothesis. The test results showed that the first hypothesis could be proven, meaning that competition was able to stimulate banks to be more efficient in creating competitive prices or equal to marginal costs in a perfectly competitive market. The results of this study were supported by Duygun et al. (2013), who proved that the response to higher level of competition would be to increase the efficiency of conventional banks. Casu and Girardone (2009) determined that increasing monopoly power did not reduce efficiency.

In contrast, Andrieş and Căpraru (2014) found that competition prevented banks from achieving optimal efficiency scales and, therefore, produced inefficiencies. Departing from the gap between theory and empirical results of previous research, the study of the competition and bank efficiency in Indonesia becomes more critical. Considering the rampant consolidation due to banking mergers, the results of this study become urgent in evaluating the IBA policy in terms of whether it has a significant impact on the efficiency of each bank in Indonesia. Thus, this study had the following objectives:

a) measuring the level of competition and banking efficiency in Indonesia, and

b) analyzing the impact of competition on banking efficiency in Indonesia.

\section{LITERATURE REVIEW AND RESEARCH HYPOTHESES}

Market structure theory can explain bank competition. The market structure is defined as a state of the market that guides aspects that significantly affect the behavior of business actors and market performance (Indonesian Constitution, 1999). These aspects include the number of buyers and sellers, barriers to entry and exit from markets, diversity of products, distribution systems, and control of market share. In general, there are two types of market structures, monopoly, and perfect competition.

According to Joesron and Fathorazzi (2012), perfect competition markets have characteristics that include a large number of sellers and buyers, the 
freedom to open and close a company, the products traded are homogeneous, the seller and the buyer are highly aware of the state of the market, and accurate mobility of economic resources (without any obstacles). Meanwhile, a monopoly market has characteristics that include only one seller, no other sellers who sell output that can adequately replace the products sold by the monopolist, and obstacles to other companies from entering the market.

The efficiency hypothesis proposed by Smirlock (1985) states that a relationship exists between the level of concentration and market share. The level of intensity is an output of the efficiency advantages owned by banks/companies to achieve a significant market share. This means an efficient company/bank will gain a considerable market share, so the industry tends to be more concentrated. Al-Obaidan (2008) stated that the level of concentration was assessed not as an anti-competitive act but instead as an impact of bank efficiency. Therefore, it is essential to maintain profitability to have a high market share (high concentration).

Atmawardhana (2006) states four things caused efficiency in financial institutions. The main factor is efficiency due to information arbitration. Second is efficiency due to the accuracy of the valuation of its assets. The third is efficiency because bank financial institutions can minimize the risks that arise, and the fourth is functional efficiency, which is related to the speed of administration and payment mechanisms carried out by a financial institution.

Maudos et al. (2002) explained that efficiency analysis could use cost minimization or profit maximization. Sometimes, the structural approach showed the production function. Meanwhile, estimating the production function can provide information showing that a bank/company is technically efficient (Maudos et al., 2002), as when managers manage the production process so that the company/bank maximizes the amount of output produced with an input that is owned (so the company operates at its production limits).

A commonly used method for estimating efficiency is the non-parametric and parametric one with a frontier approach (Nguyen \& Nghiem, 2017).
Claessens and Laeven (2004) suggested that high competition in the financial sector could stimulate increased production efficiency, quality of financial products, and the level of innovation. Increased competition is expected to reduce the cost of financial transactions because the time needed to take care of credit and investments is much shorter and will ultimately increase bank revenues (Cetorelli, 2001). The competitive banking industry has the power to reduce weak banks and, at the same time, encourage the existence of healthy banks. In contrast to the first view above, the Quiet-life Hypothesis (QLH), initiated by Berger and Hannan (1998), stated that the level of competition, as measured by the level of market concentration, reduces inefficiency. Banks did not use a low concentration level to increase productivity (increasing financing, decreasing product prices). Banks tend to dominate the banking industry market to enlarge business scale so that it enjoys a "quiet life."

According to Berger and Hannan (1998), there are several reasons for the negative relationship between bank market forces and cost-efficiency. The first reason is that market forces can encourage banks to charge higher prices to customers than they would at a competitive level. The second reason is that market power allows banks to achieve other (usually strategic) objectives while being relaxed about profit maximization. Third, bank management with market power sometimes utilizes time and resources to maintain or increase market power, which ultimately increases cost inefficiency. Finally, market power enables management to persevere without the intention of pursuing goals other than maximizing company value.

Therefore, this study had the following objectives: a) measuring the level of competition and banking efficiency in Indonesia, and b) analyzing the impact of competition on banking efficiency in Indonesia.

\section{DATA AND METHODS}

The approach used in this study was quantitative. Meanwhile, the data used was secondary. Data collection was carried out using documentation that downloaded the banks' quarterly financial state- 
ments from 2011 to 2018. Meanwhile, the sample selection method in this study was a purposive sampling selected from considerations that were determined by the researchers. Obtaining data using these techniques is considered relevant to this study. The considerations were as follows:

1) The banks with the largest total assets in Indonesia had a banking market share of more than $60 \%$ compared to other banks; and

2) These banks provided complete quarterly financial reports from 2010 to 2018.

The list of banks used as samples is in Table 1.

Table 1. Banks that met the criteria

\begin{tabular}{c:c}
\hline No. & \multicolumn{1}{c}{ Conventional banks } \\
\hline 1 & Bank Rakyat Indonesia (BRI) \\
\hdashline 2 & Bank Mandiri (MANDIRI) \\
\hdashline 3 & Bank Central Asia (BCA) \\
\hdashline 4 & Bank Negara Indonesia (BNI) \\
\hline
\end{tabular}

The equation model used to answer the question about the influence of the level of competition on bank efficiency and the role of banks in economic growth can be written in equation (1) as follows:

$$
\begin{aligned}
& \Delta \text { Efficiency }_{i, t}=\alpha+\beta_{1} \Delta \text { Efficiency }_{i, t-1}+ \\
& +\beta_{2} \Delta \text { Lerner }_{i t}+\varepsilon .
\end{aligned}
$$

The data panel method will be used to analyze the effect of the level of competition on bank efficiency. There were three estimation models in the panel data, namely:

\section{1) Common Effect Model (CEM)}

This Common Effect Model (CEM) used the Ordinary Least Square (OLS) method. This method was a combination of time series data and cross-sections, which, in other words, suggests that companies behave the same over different time periods (Widarjono, 2013). The common effect equation can be written as follows:

$$
Y_{i t}=\alpha+\beta_{1} X_{1 i t}+\beta_{2} X_{2 i t}+\ldots+\beta_{n} X_{n i t}+\mu_{i t} .
$$

2) Fixed Effect Model (FEM)
Widarjono (2013) explained that the fixed effect model uses the assumption that there were intercept differences in the regression equation. This model technique uses dummy variables to capture the existence of the intercept differences in data penalization, often called the Least Square Dummy Variable (LSDV). The estimation model can be written as follows:

$$
\begin{aligned}
& Y_{i t}=\alpha+C_{1} D_{1}+\ldots+C_{n} D_{n}+ \\
& +\beta_{1} X_{1 i t}+\beta_{2} X_{2 i t}+\ldots+\beta_{n} X_{n i t}+\mu_{i t} .
\end{aligned}
$$

\section{3) Random Effect Model (REM)}

This model solved a problem arising from the use of dummy variables in the fixed effect model in the form of a reduced degree of freedom (df), which results in a reduction in the parameter efficiency. The problem of using dummy variables was solved through a random effect model that used the error term (error term), which may be interconnected between time and individuals. The following equation describes the random effect:

$$
Y_{i t}=\beta_{1} X_{1 i t}+\beta_{2} X_{2 i t}+\ldots+\beta_{n} X_{n i t}+\epsilon_{i t} \cdot \mu_{i t} .
$$

\section{RESULTS}

After testing the models, it was found that the FEM is the right model to estimate the data in this study. Based on the estimation results with panel data through the FEM, equation (5) was obtained:

$$
\begin{aligned}
& \Delta \text { Efficiency }_{i, t}=0.1016+ \\
& +0.4633 \Delta \text { Efficiency }_{i, t-1}- \\
& -0.0008 \Delta \text { Lerner }_{i t}+\varepsilon .
\end{aligned}
$$

From equation (5), a coefficient showed how much efficiency changes if there is a change in the efficiency variable $(t-1)$ and the level of competition (Lerner), if other variables were fixed or ceteris paribus. Then, after the F-Test was done, all independent variables simultaneously had a significant effect on the dependent variable (efficiency), while the results of individual significance tests can be seen in Table 2. 
Table 2. Individual significance test results

\begin{tabular}{|c|c|c|c|c|}
\hline Variable & Coefficient & t-statistic & Probability & Sentence \\
\hline $\begin{array}{l}\text { Efficiency } \\
(\mathrm{t}-1)\end{array}$ & 0.463386 & 0.065108 & 0.0000 & Significance \\
\hline Lerner & -0.000854 & 0.000139 & 0.0000 & Significance \\
\hline C & 0.101675 & 2246.418 & 0.0000 & - \\
\hline
\end{tabular}

Table 2 shows that the efficiency variable $(t-1)$ had a significant positive effect on efficiency. Meanwhile, the Lerner variable (competition) had a significant adverse impact on productivity. In the fixed-effect model, there were different categories. In this study, time-series data $(T)$ were more numerous than cross-section data $(N)$, so this study was categorized as a multiple time series analysis. Table 3 is a cross-sectional fixed effect table of four sample banks.
Table 3. Cross sectional fixed effect test results

\begin{tabular}{l|c}
\hline \multicolumn{1}{c|}{ Bank } & Effect \\
\hline BRI & 0.000157 \\
\hline MANDIRI & $-6.64 \mathrm{E}-05$ \\
\hline BCA & $-7.55 \mathrm{E}-05$ \\
\hline BNI & $-1.55 \mathrm{E}-05$ \\
\hline
\end{tabular}

Table 3 shows that the individual effects of the four sampled banks in Indonesia varied. Most banks had a negative effect on the efficiency of commercial banks, including Mandiri Bank, BCA and BNI. Meanwhile, BRI had a positive effect on the efficiency of commercial banks.

Competition can be measured using the Lerner index with a non-structural approach. The higher the market power, the lower the compe-

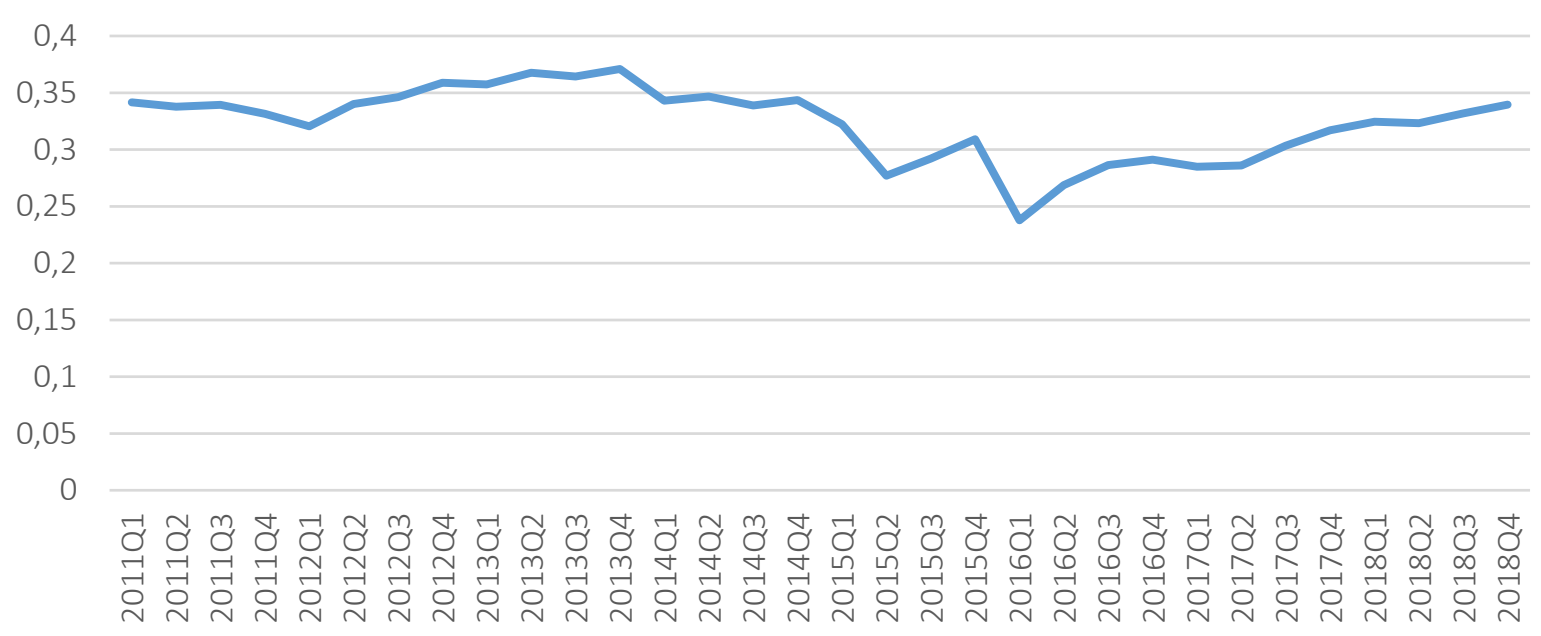

Figure 1. Lerner index by quarters, 2011-2018

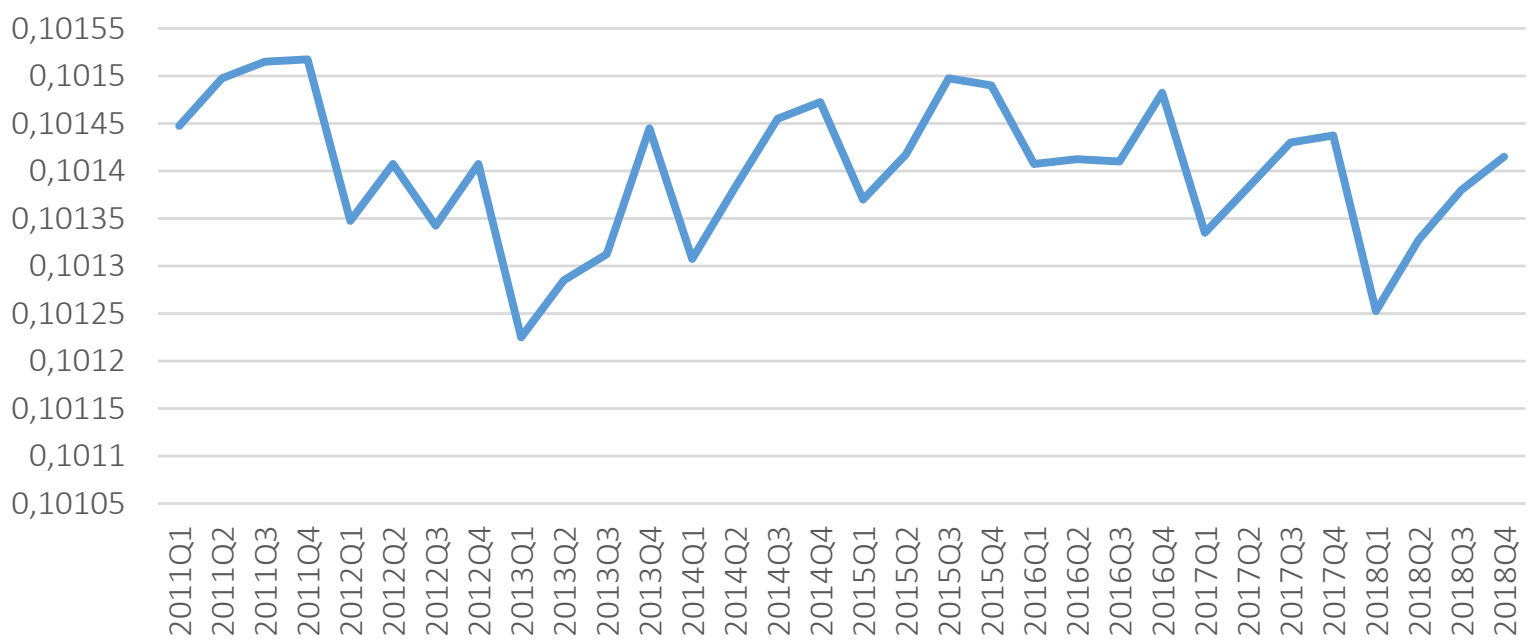

Figure 2. Efficiency score based on the cost efficiency by quarters, 2011-2018 
tition. The estimated mean of the Lerner index is shown in Figure 1.

The efficiency score is based on the cost efficiency by quarters 2011-2018 (Figure 1). Figure 2 shows how the average efficiency score, based on bank cost efficiency indicators, fluctuates, and the lowest efficiency decline occurred in 2013Q1. The efficiency scores always range from 0.1012 to 0.1015 .

\section{DISCUSSION}

In general, the value of the Lerner index showed that experiencing competition tend to fluctuate. In 2013Q4-2015Q2, bank competition in Indonesia increased, marked by a decrease in the Lerner index value. This indicated a decline in the market power of banks due to the downgrade of the UK credit rating, the crisis in Cyprus, fears of the Italian election, and unresolved political compromise related to the debt ceiling in America, all of which affect the economic growth of developing countries, including Indonesia (Bank Indonesia, 2013). These conditions could influence the decision to place funds and invest in banks that have an impact on market share. As is well known, economic conditions can trigger negative sentiment, which can lead to the release of domestic foreign investment funds.

From 2016Q1 to 2018Q4, the positive growth in the Lerner index showed that bank competition in Indonesia was lower due to bank mergers and consolidations, which led to a decline in the number of banks, followed by a decrease in the number of bank offices. In 2016, there were 32,730 bank offices; by 2018, there were only 31,618 offices, according to Financial Services Authority (2018a). On the other hand, the Lerner index also showed the market power of the banks, aside from estimating competition (Arrawatia et al., 2015). For example, from 2016Q1 to 2018Q4, the Lerner index had a positive trend. The market power of the big four banks in Indonesia had strengthened in the monopolistic market structure.

The average efficiency score, based on bank cost efficiency indicators, fluctuates. The lowest efficiency decline occurred in 2013Q1, and the efficiency scores always range from 0.1012 to 0.1015 . The efficiency score range was relatively small (10\%) since the highest efficiency value was $100 \%$ (Hadad et al., 2003). Theoretically, efficiency was measured by the results achieved by comparing input and output (Siagian, 2001). If case of inefficiency, the resulting product is not optimal because it utilizes existing inputs or specific outputs with contributions that are not minimized.

The low-cost efficiency can be caused by the relatively high inefficiency of the input (interest and labor costs) borne by banks in Indonesia. At its peak, an increase in interest expenses was USD 19 trillion and labor costs were 12 trillion in 2017Q4; in 2018Q4, interest expenses were 20 trillion and labor costs were 12 trillion, according to bank financial statements. Moreover, Bank Indonesia (BI) imposed a policy to raise the benchmark interest rate, which was a burden on banks. According to the 2018 Quarterly Monetary Policy Report, Bank Indonesia increased the BI 7-day (Reverse) Repo Rate (BI Rate)/Bank Indonesia (BI) benchmark interest rate to 6\% since November 2018.

In general, the concept of efficiency leads to the idea of achieving maximum results by optimally using existing resources. Productivity in the banking industry is a significant aspect of creating sustainable financial performance (Khan et al., 2017). Therefore, the more efficient a bank is, the healthier it is and the easier it is to achieve sustainable financial performance. According to Maudos et al. (2002), banking efficiency can be measured by analyzing cost efficiency and profit efficiency. In this study, the banks' cost efficiency will be analyzed. Economic optimization activities seek to minimize costs about market prices and the level of competition (Schaeck \& Čihák, 2008).

Competition is described as a situation where several parties compete to get certain things. In principle, interbank competition can occur because productive resources will be used to optimize profits, gain market share, and rank surveys. Four factors influence competition in the banking industry: regulation, the fast-growing demand for bank services, technological 
development, and innovation in financial markets (Maudos et al., 2002). These factors trigger a high or low intensity of competition. At the same time, high and low levels of competition can affect the efficiency of banks. This study evaluated the relationship between competition and efficiency so that banks can maintain profitability when facing competition that cannot be avoided.

The data estimation results showed that the level of competition had a significant adverse effect on efficiency. This means that the level of competition caused some inefficiencies because competition stimulates banks to obtain higher profits, rather than encouraging banks to be more efficient. For example, low competition is accompanied by higher Lerner index values. In 2018Q1-2018Q4, the Lerner index of each of the big four banks in Indonesia was $0.32,0.323$, 0.331 , and 0.339 , based on the estimation results in Figure 1. The rise in the profitability of the four big banks in Indonesia followed the increase in the Lerner index value. As an illustration, according to financial statements, the operating profit of the big four banks in Indonesia increased from 2018Q1 to 2018Q4 by 5 trillion, 11 trillion, 17 trillion and 23 trillion, respectively. This showed that the intensity of competition was reduced because the banks competed, the costs incurred for promotion were more significant and reduced bank profitability. Also, according to bank financial statements, the four big banks tend to have larger non-performing loans (NPL) from the corporate sector. Although the corporate sector gave more return, the risk is also significant. This was supported by Andrieş and Căpraru (2014), who found that an increase in competition increases bank's profitability in non-Euro-zone-group countries, so that these banks diversify their bank products and service portfolios to be able to enter the high-risk and high-return markets.

Another reason why competition is negatively associated with efficiency is that the competition encourages large banks to take on highrisk projects that have an impact on decreasing efficiency. As an illustration of the latest year's NPL risk, the exposure of the four big banks in Indonesia was BNI, 3.2\%; Mandiri Bank, 3.32\%;
BRI, 2.46\%; and BCA had the lowest NPL among the four big banks - 1.5\% (Financial Services Authority, 2018b). According to bank financial statements, triggers for NPL in the four big banks are generally due to defaults in the corporate sector. Moreover, according to the Bank Indonesia (2018), there was a policy of increasing interest rates imposed by Bank Indonesia. The results of this study were supported by Qichang et al. (2012), who showed that the four big banks in China know they are "too big to fail" and don't care whether they are profitable or not.

The four big Indonesian banks were increasingly commercialized during the financial reform. This is supported by the Quiet Life hypothesis that posits that banks that are concentrated and have a high market share lead to lower efficiency due to relaxed conditions (top market share). This condition means that banks do not have incentives to increase cost efficiency, so the banks do not try hard to minimize their costs. The results of the study are in line with The Competition-Inefficiency Hypothesis, which states that competition had the potential to cause inefficiency.

The last reason why competition reduces bank efficiency was the high activity of financing/ credit (evaluated as an output when estimating efficiency). As an illustration, from 2017 to 2018, credit activity in Indonesia's four big banks increased by $9.66 \%$ or $2,544,657$ billion Rupiah (Financial Services Authority, 2018a). The high lending activity could increase profit on the lending activity but could also increase the risk of default. Fungáčová et al. (2013) stated that competition is negatively related to bank efficiency due to increased lending activity, as the need to pursue economies of scale when dealing with customers with short-term relationships.

In addition to the high activity/credit result, competition encourages banks to improve employee performance, which can be achieved by increasing employee incentives. This was reflected in an increase in labor costs (considered as an input in estimating efficiency). For example, labor costs amounted to 12 trillion in 2017Q4. Then, in 2018Q4, the cost of labor increased to 12.8 trillion. 


\section{CONCLUSION}

Based on the estimation results, it can be concluded that the banking industry in Indonesia tended to be monopolistic, with a large number of sellers, differentiated products, sellers free to enter and exit the market, and advertising and product quality competition. The competition had a negative correlation with bank efficiency, since it encourages banks to focus on profit rather than efficiency, engage in risky projects/financing, and pursue high lending activity. Competition increases the number of bank workforce (input) to improve employee performance, resulting in inefficiency.

To maintain bank efficiency, to be able to build reliable and stable banks, and to be able to compete globally, banks need to develop a cost-conscious culture and an awareness of the burden of costs within the company. Then, banks need to invest in information technology (IT). This investment is an essential part of operational banking policy, with the excellent technique and low cost, and it takes a long time to enjoy the results. An additional recommendation is the use of a flat corporate organizational structure. Banks should decentralize decision making and centralize support functions, such as merging Automatic Teller Machines (ATM) networks, developing joint human resources departments, or developing joint products and branchless banking.

Bank competition that leads to a monopolistic market structure stimulates banks to achieve higher profits and put bank projects and financing at high risk. Since the four big banks in Indonesia were classified as monopolistic, there will be competition, especially non-price competition, such as product differentiation or market segmentation and service improvement. To maintain bank services that can satisfy customers, banks also need to provide incentives for their employees by increasing the allocation of employee salary expenses. The provision of incentives was expected to improve performance and then bank efficiency. Banks also increased lending activity to achieve the expected profit despite the risk of default. Therefore, regulators can provide incentives for banks with excellent efficiency, so that banks try to realize efficiency through their behavior (cost-conscious culture). Incentives were expected to increase awareness about cost-conscious perception. Banks should focus on improving services by utilizing and developing IT advancements, developing products according to customer interests, and improving HR performance, while maintaining a cost-conscious culture and branchless banking.

The novelty of this study is that bank competition has been found to negatively affect the efficiency of banks in Indonesia. This study is expected to become a new reference for science. It is proposed for further research to include control variables in the model.

\section{AUTHOR CONTRIBUTIONS}

Conceptualization: Setyo Tri Wahyudi, Rihana Sofie Nabella.

Data curation: Kartika Sari.

Formal analysis: Rihana Sofie Nabella.

Investigation: Rihana Sofie Nabella.

Methodology: Setyo Tri Wahyudi, Rihana Sofie Nabella, Kartika Sari.

Project administration: Setyo Tri Wahyudi, Kartika Sari.

Supervision: Setyo Tri Wahyudi.

Validation: Setyo Tri Wahyudi, Rihana Sofie Nabella, Kartika Sari.

Visualization: Rihana Sofie Nabella, Kartika Sari.

Writing - original draft: Rihana Sofie Nabella, Kartika Sari.

Writing - review \& editing: Setyo Tri Wahyudi, Rihana Sofie Nabella. 


\section{ACKNOWLEDGMENT}

The authors would like to thank all those who have contributed to the completion of this article, especially the leadership of the Department of Economics and the Faculty of Economics and Business, Brawijaya University, who provided facilitation for publication in reputable international journals.

\section{REFERENCES}

1. Abbasoglu, F. O., Aysan, A. F., \& Gunes, A. (2007). Concentration, competition, efficiency and profitability of the Turkish Banking sector in the post crises period (MPRA Paper No. 5494). Retrieved from http://mpra. ub.uni-muenchen.de/5494/

2. Al-Obaidan, A. M. (2008). Market structure, concentration and performance in the commercial banking industry of emerging market. European Journal of Economics, Finance, and Administrative Science, 1(12), 104-114. Retrieved from https://www.researchgate.net/ publication/255572872_Market_Structure_Concentration_ and_Performance_in_the_Commercial_Banking_Industry_of_ Emerging_Markets

3. Andrieş, A. M., \& Căpraru, B. (2014). The nexus between competition and efficiency: The European banking industries experience. International Business Review, 23(3), 566-579. https://doi org/10.1016/j.ibusrev.2013.09.004

4. Arrawatia, R., Misra, A. K., \& Dawar, V. (2015). Bank competition and efficiency: Empirical evidence from Indian market. International Journal of Law and Management, 57(3), 217231. Retrieve from http://dx.doi. org/10.1108/IJLMA-03-2014-0029

5. Atmawardhana. (2006). Analisis efisiensi Bank Umum Syariah dan Bank konvensional yang memiliki unit usaha Syariah di Indonesia, setelah pemberlakuan UndangUndang No. 10 Tahun 1998 tentang Perbankan (Pendekatan Data Envelopment Analysis) [Efficiency Analysis of Sharia Commercial Banks and Conventional Banks which is having Sharia Business Units in Indonesia, after the enactment of Law No. 10 of 1998 concerning Banking (Data Envelopment Analysis Approach)] (Unpublished Thesis). Faculty of Economic, Indonesia Islamic University, Yogyakarta, Indonesia.

6. Bank Indonesia. (2013). Laporan Perekonomian Indonesia [Indonesian Economic Report]. Jakarta: Bank Indonesia, Departemen Kebijakan Ekonomi dan Moneter. Retrieved from https://www.bi.go.id/id/publikasi/ laporan/Documents/LPI\%20 2013\%20ID\%20-\%20Cover,\%20 Daftar\%20Isi,\%20Pengantar.pdf

7. Bank Indonesia. (2018). Laporan Kebijakan Moneter Triwulan III 2018 [Quarterly Monetary Policy Report of 2018]. Jakarta: Bank Indonesia, Department of Economic and Monetary Policy. Retrieved from https://www.bi.go. $\mathrm{id} /$ id/publikasi/laporan/Documents/Laporan-Kebijakan-Moneter-Triwulan-III2018.pdf

8. Berger, A., \& Hannan, T. (1998). The efficiency cost of market power in the banking industry: A test of the "quiet life" and related hypotheses. Review of Economics and Statistics, 80(3), 454-465. https://doi. org/10.1162/003465398557555

9. Casu, B., \& Girardone, C. (2009). Testing the relationship between competition and efficiency in banking: A panel data analysis. Economics Letters, 105(1), 134-137. https://doi.org/10.1016/j.econlet.2009.06.018

10. Cetorelli, N. (2001). Competition among banks: Good or bad? Economic Perspective, 25(QII), 3848. Retrieved from https://ideas. repec.org/a/fip/fedhep/y2001iqiip38-48nv.25no.2.html
11. Claessens, S., \& Laeven, L. (2004). What drives Bank competition? Some International evidence. Journal of Money, Credit, and Banking, 36(3), 563-583. Retrieved from https://econpapers.repec.org/ article/mcbjmoncb/v_3a36_3ay_3 a2004_3ai_3a3_3ap_3a563-83.htm

12. Duygun, M., Sena, V., \& Shaban, M. (2013). Schumpeterian competition and efficiency among commercial banks. Journal of Banking and Finance, 37(12), 51765185. https://doi.org/10.1016/j. jbankfin.2013.07.003

13. Financial Services Authority. (2004). Arsitektur Perbankan Indonesia [Indonesian Banking Architecture]. Jakarta: Otoritas Jasa Keuangan. Retrieved from https://www.ojk.go.id/id/kanal/ perbankan/arsitektur-perbankanindonesia/Pages/PengaturanPerbankan.aspx

14. Financial Services Authority. (2018a). Statistik Perbankan Indonesia tahun 2018 [The Indonesian Banking Statistics]. Otoritas Jasa Keuangan. Retrieved from https://www.ojk.go.id/id/ kanal/perbankan/data-dan-statistik/statistik-perbankan-indonesia/ Default.aspx

15. Financial Services Authority. (2018b). Laporan Keuangan Perbankan [Banking Finansial Reports]. Otoritas Jasa Keuangan. Retrieved from https://ojk.go.id/id/ kanal/perbankan/data-dan-statistik/laporan-keuangan-perbankan/ Default.aspx

16. Fungáčová, Z., Pessarossi, P., \& Weill, L. (2013). Is bank competition detrimental to efficiency? Evidence from China. China Economic Review, 27, 121 134. https://doi.org/10.1016/j. chieco.2013.09.004 
17. Hadad, M. D., Santoso, W., Mardanugraha, E., \& Illyas, D. (2003). Pendekatan parametrik untuk efisiensi Perbankan Indonesia [Parametric Approach to Indonesian Banking Efficiency]. Jurnal Penelitian, 1-27.

18. Indonesian Constitution. (1999). Law No. 5 of 1999 concerning Prohibition of Monopolistic Practices and Unfair Business Competition. Retrieved from https://asean-competition.org/file/ pdf_file/law_5_year_1999_.pdf

19. Joesron, T. M., \& Fathorrozi, M. (2012). Teori ekonomi mikro [Theory of Micro-Economy]. Yogyakarta: Grata Ilmu.

20. Khan, H. H., Kutan, A. M., Ahmad, R. B., \& Gee, C. S. (2017). Does higher bank concentration reduce the level of competition in the banking industry? Further evidence from South East Asian economies. International Review of Economics \& Finance, 52, 91106. http://dx.doi.org/10.1016/j. iref.2017.09.006

21. Maudos, J., Pastor, J. M., Pérez, F., \&, Quesada, J. (2002). Cost and profit efficiency in European banks. Journal of International Financial Markets, Institutions and Money, 12(1), 33-58. http:// dx.doi.org/10.1016/S10424431(01)00051-8
22. Naceur, S. B., Ben-Khedhiri, H., \& Casu, B. (2009). What drives efficiency of selected MENA banks? A meta-frontier analysis (IMF Working Paper No. WP/11/34) Retrieved from https://www.imf. org/external/pubs/ft/wp/2011/ wp1134.pdf

23. Nguyen, T. P. T., \& Nghiem, S. H. (2017). The effects of competition on efficiency: The Vietnamese Banking industry experience. The Singapore Economic Review, 65(06), 1507-1536. https://doi. org/10.1142/s0217590817500114

24. Schaeck, K., \& Čihák, M. (2008). How does competition affect efficiency and soundness in banking? New empirical evidence (Working Paper Series No. 932). European Central Bank. Retrieved from https://www.ecb.europa.eu/ pub/pdf/scpwps/ecbwp932.pdf

25. Siagian, S. P. (2001). Sistem informasi manajemen [Management of information system]. Jakarta: Bumi Aksara.

26. Smirlock, M. (1985). Evidence of the (Non) relationship between concentration and profitability in Banking. Journal of Money, Credit, and Banking, 17(1), 69-83. Retrieved from https://econpapers. repec.org/article/mcbjmoncb/ v_3a17_3ay_3a1985_3ai_3a1_3ap 3a69-83.htm
27. Suseno, \& Abdullah, P. (2003). Seri kebanksentralan: Sistem dan kebijakan perbankan di Indonesia [The central banking series: Indonesian banking system and policy]. Jakarta: Pusat Pendidikan dan Studi Kebanksentralan. Retrieved from http://lib.ui.ac.id/ detail id $=20162303$

28. Utama, C. (2006). Mengukur tingkat kesehatan bank di Indonesia [Measuring the soundness of banks in Indonesia]. Bina Ekonomi, 1(1), 1-120. Retrieved from https://www.neliti. com/publications/12970/mengukur-tingkat-kesehatan-bank-diindonesia

29. Widarjono, A. (2013). Ekonometrika pengantar dan aplikasinya [Introduction to econometrics and its applications]. Yogyakarta: Ekonisia.

30. Williams, J. (2012). Efficiency and market power in Latin American banking. Journal of Financial Stability, 8(4), 263-276. https://doi. org/10.1016/j.jfs.2012.05.001

31. Ye, Q., Xu, Z., \& Fang, D. (2012). Market structure, performance, and efficiency of the Chinese banking sector. Economic Change and Restructuring, 45, 337-358. https://doi.org/10.1007/s10644012-9123-6 